\title{
MEMBANGUN KREATIVITAS ANAK MELALUI PERMAINAN TRADISIONAL JAWA
}

\author{
AHMAD TABI'IN \\ ahmadtabiin6@gmail.com \\ IAIN Pekalongan
}

\begin{abstract}
Abstrak
Era globalisasi yang penuh dengan persaingan saat ini membutuhkan kreativitas yang sangat tinggi pada segala lini kehidupan. Salah satunya pada sistem pengajaran di sekolah. Pembelajaran formal saat ini masih menekankan pada cara berpikir konvergen pada peserta didiknya, sementara kemampuan berpikir divergen atau kreatif masih jarang diperhatikan, hal ini menjadi sebuah kekhawatiran yang menyebabkan kreativitas verbal peserta didik akan menurun. Kreativitas bukanlah sesuatu yang given, melainkan harus diupayakan untuk memilikinya. Kreativitas hanya bisa dimiliki oleh mereka yang mempunyai curiosity, pendorong untuk bisa melakukan sesuatu demi mengatasi kondisi tertentu. Permainan pada anak mempunyai pengaruh pada perkembangan pribadi anak itu sendiri. Ada berbagai permainan yang dapatmeningkatkan kreativitas bagi peserta didik salah satunya adalah permainan tradisional. Permainan tradisional merupakan simbolisasi dari pengetahuan yang turun nenurun dan mempuyai bermacam-macam fungsi atau pesan dibaliknya.
\end{abstract}

Kata Kunci: Membangun, Kreativitas Anak, Permainan TradisionalJawa

\begin{abstract}
In this globalization era which full of competition need high creativity in all aspects of life. One of them is on teaching system in schools. Formal learning nowdays is still emphasis on the way to think convergent for students, while the ability to think divergent or creative is still rarely considered, it is become a concern that cause to verbal creativity of learners
\end{abstract}


will decline. Creativity is not something given, but must be pursued to have it. Creativity only be owned by those who have the curiosity, a booster to be able to do something to overcome certain conditions. Games for children having an influence on the personal development of the children themselves. There are many various games which can increase the creativity of students, one of it is the traditional games. Traditional game is a symbol of knowledge hereditarily and having various functions or message behind it.

Keywords: Building, Children Creativity, Javanese Traditional Games

\section{A. PENDAHULUAN}

Bakat dan kreativitas anak dalam belajar adalah termasuk salah satu faktor yang sangat penting untuk dapat mendorong keberhasilan pelaksanaan pendidikan. Apabila faktor ini kurang diperhatikan, biasanya akan membawa akibat pada diri anak didik dan guru yaitu tidak dapat mencapai tujuan pendidikan sekolah secara baik. Mengembangkan bakat dan kreativitas anak dalam belajar bukanlah suatu pekerjaan yang mudah pekerjaan ini sangat banyak tantangannya baik dari segi pengetahuan, pengalaman, fasilitas dan sistem kerja-sama yang baik dituntut dari berbagai pihak. Dalam melaksanakan tugas ini adakalanya berjalan lancar, hal ini boleh jadi karena adanya faktor penunjang terhadap apa yang diperlukan dan begitu juga sebaliknya.

Dalam usaha mengembangkan bakat dan minat serta kreativitas anak didik perlu adanya serangkaian peraturan pembinaan, Latihan dan dorongan bahkan hukuman yang sifatnya sistimatis terjadwal dan berencana agar segala yang dimilik sertiap anak didik dapat menjadi aktual serta berfungsi dengan sebaik-baiknya. Membiarkan seorang anak berkembang sesuai dengan azas kematangannya saja, biasanya dapat menyebabkan perkembangannya tidak menjadi sempurna. 
Kemampuan berpikir kritis akan berubah menjadi berpikir raguragu dan berubah menjadi sikap pembosan bahkan acuh terhadap tugas-tugas rutin yang diberikan di sekolah.

Dunia anak adalah dunia bermain, maka dalam lembaga pendidikan dini (Taman Kanak-kanak) diberikan pelajaran yang dapat merangsang jiwa anak yaitu dengan bermain. Permainan pada anak mempunyai pengaruh pada perkembangan pribadi anak itu sendiri. perkembangan ungkapan kreatif, perkembangan aspek sosial dan lainlain. Ada berbagai permainan yang dapat meningkatkan kreativitas anak salah satunya adalah permainan tradisional. Permainan tradisional merupakan simbolisasi dari pengetahuan yang turun nenurun dan mempuyai bermacam- macam fungsi atau pesan dibaliknya Hayuningtyas, permainan tradisional merupakan hasil budaya yang besar nilainya bagi anak- anak dalam rangka berfantasi, berekreasi, berkreasi, berolah raga yang sekaligus sebagai sarana berlatih untuk kehidupan bermasyarakat, ketrampilan, kesopanan, serta ketegasan.

Sebagai salah satu usaha dalam mengembangkan bakat, minat dan kreativitas anak didik di sekolah dengan cara memberikan permainan tradisional, permainan tradisional juga memberikan anak kreatif pada saat bermain. Anak dikatakan kreatif jika anak ini mampu untuk mengekspresikan diri dan menciptakan suatu bentuk dalam bermain. Kreativitas anak akan berkembang jika anak mempunyai ideide, pokok pikiran yang baru, sehingga anak mempunyai kesempatan untuk memperoleh pengetahuan baru dan memperkaya pengalaman dengan berbagai permainan.

\section{B. MAKNA KREATIVITAS}

Menurut Barron dalam Utami Munandar menyatakan kreativitas adalah kemampuan untuk menghasilkan/menciptakan sesuatu yang 
baru, selain itu kreativitas merupakan titik pertemuan yang khas antara tiga atribut psikologis, intelegensi, gaya kognitif dan kepribadian/ motivasi, bersama-sama ketiga segi dari alam pikiran ini membantu memahami apa yang melatarbelakangi induvidu yang kreatif. ${ }^{1}$

Menurut Haefele kreativitas adalah kemampuan untuk membuat kombinasi-kombinasi baru yang mempunyai makna sosial.2 Definisi Haefele ini menunjukkan bahwa tidak keseluruhan produk itu harus baru, tetapi kombinasinya. Hidup dalam suatu masa dimana ilmu pengetahuan berkembang dengan pesatnya untuk digunakan secara konnstruksi maupun deduktif. Suatu adaptasi kreatif merupakan satusatunya kemungkinan bagi suatu bangsa yang sedang berkembang. Untuk dapat mengikuti perubahan- perubahan yang terjadi, untuk dapat menghadapi problema-problema yang semakin kompleks sebagai pribadi maupun sebagai kelompok atau suatu bangsa kita harus mampu memikirkan, membentuk cara-cara baru atau mengubah cara-cara lama secara kreatif, agar kita dapat survive dan tidak hanyut atau tenggelam dalam persaingan antar bangsa.

Kraetivitas menurut Maslow kretaivitas merupakan manifestasi dari induvidu yang berfungsi sepenuhnya karena dengan berkreasi orang dapat mewujudkan (mengaktualisasikan) dirinya dan perwujudan/aktualisasi diri merupakan kebutuhan pokok pada tingkat tertinggi dalam hidup manusia. Kreativitas atau berfikir kreatif sebagai kemampuan untuk melihat bermacam-macam kemungkinan penyelesaian terhadap suatu masalah. Kreatif tidak hanya bermanfaat bagi diri pribadi dan bagi lingkungan tetapi juga memberikan kepuasan kepada induvidu. Dalam era pembangunan ini kesejahteraan dan kejayaan masyarakat dan Negara bergantung pada teknologi baru. Untuk

1 Utami Munandar, Mengembangkan Bakat dan Kreativitas Anak Sekolah, (Jakarta: Gramedia Widiasarana Indonesia, 1992), hlm. 21.

2 Utami Munandar, Mengembangkan... 
mencapai hal itu perlulah sikap, pemikiran dan perilaku kratif di pupuk sejak dini. ${ }^{3}$

Dari beberapa definisi yang dipaparkan, ada beberapa hal penting yang bisa disarikan dari kreativitas bahwa; (1) Mengarah pada sesuatu yang baru, (2) Merupakan usaha untuk beradaptasi dengan kesulitan atau tuntutan, (3) Membutuhkan entri/ pengetahuan yang sudah ada sebelumnya/pengalaman, (4) Kreativitas bisa dipelajari, bukan hadiah dari Tuhan, (5) Lingkungan sangat mempengaruhi kemampuan kreativitas, (6) Kreativitas membutuhkan proses, bukan sesuatu yang langsung jadi dalam sekejap, (7) Kreativitas sebagai tanda kemampuan mengembangkan diri.

Dari pemahaman beberapa definisi ini bisa dimengerti bahwa, kreativitas bukanlah sesuatu yang given, melainkan harus diupayakan untuk memilikinya, ada proses belajar yang harus dilewati, ada pengetahuan yang harus dikuasai sebagai basic dari kreativitas itu, juga kreativitas membutuhkan kemauan/desire. Terlihat dari uraian Torrance, bahwa kreativitas timbul sebagai usaha memahami dan mengatasi kesenjangan/kesulitan hidup. Demikian pula yang digambarkan Sutan Takdir Alisyahbana, bahwa kreativitas berfungsi ketika manusia bertingkah laku berevolusi, menyesuaikan diri terhadap perubahan alam. Berarti dibutuhkan will dalam membangun kreativitas. Bisa dipahami juga bahwa kreativitas hanya bisa dimiliki oleh mereka yang mempunyai curiosity. Curiosity itu yang menjadi pendorong untuk bisa melakukan sesuatu demi mengatasi kondisi tertentu. Apabila kreativitas bukanlah given by God, berarti keluarga memiliki peranan besar terhadap pertumbuhan jiwa kreativitas anak, seperti dikatakan Drevdahl, karena keluarga merupakan sekolah pertama bagi anak, maka

${ }^{3}$ Abraham Maslow, Motivation and Personality, (New York: Harper, 1945), hlm. 60. 
pengaruh yang datang dari keluarga adalah pengaruh pertama yang akan membentuk/membantu perkembangan anak.

Agar pengarahan/pengajaran materi apapun kepada anak bisa berhasil, termasuk didalamnya mengarahkan anak untuk kreatif, haruslah dimulai dari usia dini. Usia dini, seperti yang "dijual" di iklaniklan, merupakan golden stage si anak, dimana system memorynya sangat mudah menerima dan merekam informasi apapun, sehingga materi apapun akan diterimanya dengan baik. Oleh karenanya penting bagi orang tua, keluarga dan pendidik di sekolah untuk benar-benar memahami masa penting anak, apa saja tugas perkembangannya pada masa-masa itu, untuk selanjutnya dapat dengan semaksimal mungkin mencukupi kebutuhan si anak agar seluruh potensinya terbina. Termasuk di dalamnya daya kreativitas anak.

\section{Kreativitas pada Anak}

Kreativitas sangat penting untuk dikembangkan sejak usia dini, seperti yang dikemukakan oleh Munandar, bahwa:4

Kreativitas yang memungkinkan manusia meningkatkan kualitas hidupnya. Dalam era pembangunan ini tidak dapat dipungkiri bahwa kesejahteraan dan kejayaan masyarakat dan Negara bergantung pada sumbangan kreatif, berupa ide-ide baru, penemuan-penemuan baru, dan teknologi baru dari anggota masyarakatnya. Untuk mencapai hal itu, perlulah sikap dan

4 Utami Munandar, Pengembangan Kreativitas Anak Berbakat, (Jakarta: PT Rineka Cipta,2009), hlm. 46 
perilaku kreatif dipupuk sejak dini, agar anak didik kelak tidak hanya menjadi konsumen pengetahuan baru dan pencari kerja, tetapi mampu menciptakan pekerjaan baru (wiraswasta).

Dari uraian di atas dapat diketahui bahwa kreativitas perlu dikembangkan sejak usia dini, kreativitas merupakan kemampuan umum untuk menciptakan sesuatu yang baru, baik berupa produk atau gagasan baru yang dapat diterapkan dalam memecahkan masalah atau sebagai kemampuan untuk melihat unsur-unsur yang sudah ada sebelumnya.Dengan kreativitas seseorang dapat mewujudkan atau mengaktualisasikan dirinya yang merupakan kebutuhan pokok tertinggi dalam hidup manusia. Banyak factor yang mempengaruhi kreativitas anak usia dini:

a. Faktor Pendukung Kreativitas

Dalam perkembangan kreativitas tentunya ada beberapa factor yang dapat mendukung ataupun menghambat perkembangan kreatvitas tersebut. Dalam hal ini yang menjadi faktor pendukung dalam perkembangan kreativitas menurut Semiawan dalam (Adhipura, 2001, 46) meninjau faktor pendorong kreativitas dari segi lingkungan sekolah. Ia mengemukakan bahwa kebebasan dan keamanan psikologis merupakan kondisi penting bagi perkembangan kreativitas. Anak merasa bebas secara psikologis, jika terpenuhi persyaratan berikut ini:

1. Guru menerima siswa sebagaimana adanya, tanpa syarat, dengan segala kelebihan dan kekurangannya serta memberikan kepercayaan bahwa pada dasarnya anak baik dan mampu,

2. Guru mengusahakan suasana agar siswa tidak merasa "dinilai" dalam arti yang bersifat mengancam, dan 
3. Guru memberikan pengertian dalam arti dapat memahami pemikiran, perasaan dan perilaku siswa, dapat menempatkan diri dalam situasi siswa dan melihat dari sudut pandang siswa.

b. Faktor Penghambat Kreativitas

Selain faktor pendukung yang telah dipaparkan diatas, tentunya juga terdapat faktor penghambat yang salah satunya di kemukakan oleh Amabile dalam Munandar, menyatakan bahwa ada empat cara yang dapat mematikan kreativitas anak, yaitu pertama evaluasi, dalam memupuk kreativitas anak, guru hendaknya tidak memberikan evaluasi atau menunda pemberian evaluasi sewaktu anak sedang asyik berkreasi. ${ }^{5}$ Bahkan menduga akan dievaluasipun dapat mengurangi kreativitas anak. Kedua, hadiah. Kebanyakan orang percaya bahwa memberi hadiah akan memperbaiki atau meningkatkan perilaku tersebut.

Ternyata pemberian hadiah dapat merusak motovasi intrinsik dan mematikan kreativitas. Ketiga, persaingan. Kompetisi atau persaingan lebih kompleks dari pada pemberian evaluasi atau hadiah secara tersendiri, karena kompetisi meliputi keduanya. Biasanya persaingan terjadi apabila anak merasa bahawa pekerjaannya akan dinilai terhadap pekerjaan anak lain dan yang terbaik akan menerima hadiah. Hal ini terjadi dalam kehidupan sehari-hari dan sayangnya dapat mematikan kreativitas. Keempat, lingkungan yang membatasi belajar. Belajar dan kreativitas tidak dapat ditingkatkan dengan paksaan. Jika belajar dipaksakan dengan lingkungan yang sangat membatasi, maka minat intrinsik anak dapat dirusak.

5 Utami Munandar, Mengembangkan Bakat dan Kreativitas Anak Sekolah, (Jakarta: Gramedia, 2004), hlm. 233 
Faktor pendukung dan penghambat yang telah diapaparkan penulis dapat disimpulkan bahwa perkembangan kreativitas tidak lepas dari peran orang tua maupun peran tutor PAUD. Orangtua serta tutor PAUD dapat menjadi faktor pendukung apabila keduanya dapat bekerja sama dengan baik dalam mengembangkan kreativitas anak usia dini, sebaliknya apabila orangtua maupun tutor PAUD tidak dapat bekerja sama dengan baik maka akan berdampak kurang baik bagi perkembangan kreativitas anak itu sendiri.

Perkembangan kreativitas pada umumnya mengikuti polapola yang dapat diramalkan, mulai dari tahap awal perkembangan anak, dunia bermainnya sampai pada tahapan selanjutnya kettika ia dewasa. Karena kreativitas merupakan bagian dari perkembangan kognisi maka kreativitas dapat ditinjau dari perkembangan kognitif, berdasarkan teori kognitif Jean Piaget. Menurutnya ada empat tahapan perkembangan kognitif, yang dalam penjelasan berikut juga akan dijabarkan dari segi perkembangan kreativitasnya, termasuk proses belajar, yaitu: 6

1. Tahap Sensori Motorik

Tahap ini dimulai dari kelahiran sampai usia 2 tahun, dimana anak belajar dan berusaha mencapai kematangan dalam memfungsikan saraf sensori motoris, yaitu saraf yang ada pada tangan, kaki dan seluruh persendian. Mampu berlari, walau tidak kencang adalah target yang seharusnya mampu dicapai anak pada saat umurnya 2 tahun. Pada tahap ini, interaksi anak dengan mileunya masih terpaku sekitar keluarga, terutama keluarga inti, atau orang yang satu rumah dengannya. Interaksi dengan lingkungan lebih berorientasi pada gerakan otot-otot dan

6 Mc Cormak, A.J. Piagetian, Theory and the Development of Creative Thinking, (Ohio:Charles E. Merril, 1982), hlm. 230 
saraf motoriknya, ia suka menyentuh dan memegang sesuatu dengan erat, dan lebih cenderung tergantung dari stimulus dari lingkungannya.

Apabila orang tua dan keluarga dekatnya sering menstimulasi untuk berjalan maka kemampuan berjalannya akan lebih cepat dikuasai dibandingkan anak yang kurang mendapat stimulasi. Mengenai kreativitas, piaget menjelaskan pada usia ini, kemampuan berkreasi masih nol, karena semua kegiatannya hanya berorientasi fisik yang bersifat refleksif, karena pandangannya terhadap objek masih belum permanen, mudah dialihkan. Ia belum mengenal konsep ruang dan waktu, konsep tentang dirinya dan hubungan dengan orang lain, sehingga belum mampu menciptakan sesuatu.

2. Tahap Pra Operasional

Tahap ini berlangsung dari usia 2-7 tahun, disebut juga tahap intuisi karena perkembangan kognisinya memperlihatkan kecendrungan yang ditandai oleh situasi intuitif. Ini disebabkan perbuatannya tidak didasari pertimbangan rasional melainkan didorong oleh perasaan, kecendrungan alamiah, peniruan sikapsikap yang didapat dari orang yang bermakna, serta lingkungan sekitarnya. Anak bersifat egosentris di usia ini, yang dalam pandangan Kartono, berbentuk naïf.7Karena sifatnya itu, ia sering bertentangan bahkan dengan orang tuanya, yang diistilahkan sebagai masa Trotzalter(penentangan) pertama, karena ia lebih belajar untuk mengikuti kemauan dan perasaannya. ${ }^{8}$

\footnotetext{
7 Kartini Kartono, Psikologi Perkembangan Anak, (Jakarta: CV Mandar Maju, 1995), hlm. 20

${ }^{8}$ Haditono, Psikologi perkembangan (pengantar dalam berbagai bidangnya, (Yogyakarta: Gajah Mada
} 
Daya kreativitas pada usia ini sudah mulai tumbuh karena anak sudah memiliki memory, mulai memahami keterkaitan ruang dan waktu walaupun secara sederhana, mampu memikirkan masa lalu dan masa datang sesuai kemampuan imajinasi dan kekuatan memori serta daya tangkapnya, meskipun rentang waktu yang diingat dan difikirkannya masih sangat pendek. Selain itu, anak memiliki kemampuan untuk menterjemahkan fenomena alam dan sesuatu yang ada di lingkungannya secara animistic dan antropomorfik. Animistik adalah menjelaskan fenomena alam dengan menggunakan perumpamaan hewan. Sementara antropomorfik adalah menjelaskan fenomena alam dengan perumpamaan manusia. ${ }^{9}$ Seperti misalnya ketika seorang gadis kecil say bye kepada bunga-bunga, ia membayangkan bunga tersenyum kepadanya.

Kemampuan imajinasi pada anak-anak merupakan kemampuan dasar kreativitas. Tanpa adanya imajinasi yang melampaui pemahaman umum, sebuah hal baru akan sulit tercipta, seperti halnya penemuan sepeda, pastilah diawali dari angan-angan untuk bisa berjalan dengan menaiki sesuatu agar bisa lebih cepat sampai di tujuan dibanding dengan berjalan kaki. Untuk bidang keagamaan, pada usia ini menanamkan agama pada anak bisa dilakukan dengan dongeng, Ernest menyebut masa ini dengan the Fairy Tale Stage.10 Daya fantasinya yang sangat tinggi bisa dimanfaatkan untuk

University Press, 2004), hlm. 67

${ }_{9}^{9}$ Mohammad Ali, Mohammad Asrori, Psikologi Remaja: Perkembangan

Peserta Didik, (Jakarta: Penerbit

Bina Aksara, 2005), hlm. 48

10 Ernest Harms, The Development Of Religious on Children, (Ohio:

Charles E. Merril, 1988), hlm. 113 
mengenalkan konsep kekuasaan Tuhan melalui dongeng yang dikarang, walaupun kurang masuk akal.

3. Tahap Operasional Konkret

Mulai usia 7-11 tahun perkembangan kognitif anak memasuki tahap konkret, karena anak mulai memahami realita yang terjadi di sekitarnya, sehingga ia mulai belajar untuk objektif, egoisnya berkurang, mulai bisa memahami fikiran dan perasaan orang lain, walaupun tidak sepenuhnya. ${ }^{11}$ Mengenai kreativitasnyapun sudah mulai berkembang, karena daya imajinasinya tetap tinggi sedangkan konsep ruang dan waktu yang ada di fikirannya makin terbentuk dengan sempurna. Sebagai contoh, sebuah lomba menggambar pernah diadakan untuk menghibur anak-anak penghuni penampungan korban Tsunami Aceh yang terjadi tahun 2006. Peserta lomba adalah anak-anak yang masih di usia SD, berarti tidak lebih dari 12 tahun. Dari semua gambar yang masuk, 90\% diantaranya adalah gambar air yang menggenang begitu luas, dan gambar rumah atau hanya atap rumah yang hancur terseret arus.

Beberapa anak yang kehilangan keluarganya bahkan menggambar ayah dan ibu atau kakaknya dalam posisi tidur, diantara genangan air (seakan terbawa Tsunami). Kesemua itu mengilustrasikan terjadinya Tsunami, padahal lomba diadakan setelah berbulan-bulan pasca Tsunami. Lomba menggambar itu menjadi penyaluran kreativitas mereka, yang didasari oleh pengalamandan memori, bahkan tersalurkan juga perasaan mereka walaupun ketika menggambar tidak lagi meneteskan air mata karena kemampuan mereka menyadari realita sudah

11 Bybee R.W. and R.B. Sund, Piaget for Educators, (Ohio: Charles E. Merril, 1982), hlm. 53 
semakin berkembang. Mileu tetap memegang peranan penting, dan ini terlihat pada lomba menggambar ini, dimana kreativitas mereka dipengaruhi oleh stimulus yang mereka dapatkan dari kejadian di lingkungan. Dalam usaha membangkitkan jiwa agama anak, di usia ini mulai bisa dikenalkan konsep Tuhan secara lebih mendekati kebenaran seperti yang diajarkan agama. Karena kemampuan akal yang sudah bisa memikirkan realitas, atau the Realistic Stage, dalam istilah Ernest.

4. Tahap Operasional Formal

Setelah 11 tahun, untuk selanjutnya kemampuan kognisi anak memasuki tahap operasional formal. Kemampuannya berfikir logis hampir menyertai seluruh perbuatannya. Aspek moral dan sensitivitasnya terhadap dunia luar semakin berkembang baik. Ia belajar memisahkan antara rasio dan perasaannya. Walaupun ia tidak selalu berbuat rasional, karena pada masa remaja. Sekitar usia 15-18 tahun, anak akan memasuki masa Strung and Drum, yaitu masa yang penuh dengan kegoncangan, ketidakstabilan emosi, yang kadang mengaburkan pemikiran rasional yang awalnya telah mulai dimiliki. ${ }^{12}$ Untuk sisi kreativitasnya, masa-masa ini merupakan masa yang potensial dan kondusif untuk menumbuhkembangkan kreativitas sampai tingkat yang lebih tinggi.

Seiring dengan relasi sosial yang sangat meluas, bukan hanya dekat rumah atau sebatas teman sekolah, namun jauh lebih dari itu, apalagi dengan adanya tekhnologi internet yang menyediakan media seperti friendster, facebook, twitter dan

12 Siti Rahayu Haditono, Psikologi Perkembangan: Pengantar dalam Berbagai Bidangnya, (Yogyakarta: Gajah Mada University Press, 2004), hlm. 17. 
semacamnya yang menstimulasi anak melanglang jauh dari dunia keluarga. Mileu pergaulan anak yang sangat jauh meluas dari sebelumnya akan memberikan banyak pengaruh dan tidak selamanya pengaruh itu negatif ataupun positif sifatnya. Dari perkembangan relasi, akan timbul ide- ide baru. Misalnya ide nge-band, atau mencari kerja sampingan di luar sekolah (yang positif) tanpa sepengetahuan orang tua untuk membantu ekonomi keluarga. Karena pada masa ini, anak sudah mulai mampu memikirkan hal yang abstrak, yang terus berkembang, maka anak sudah bisa memahami nilai agama yang lebih abstrak, seperti nilai-nilai ibadah yang dijelaskan agama, konsep pahala dan dosa, surga dan neraka, serta konsep-konsep abstrak lainnya yang ada di dalam agama. Ernest menyebut masa ini dengan the Individual Stage.

Demikian penjelasan teori kognisi dan kreativitas Jean Piaget yang disertai analisa dari sisi proses belajar, pengaruh mileu. Jika dikembalikan pemikiran kepada unsur-unsur penting kreativitas yang telah disebutkan di atas, maka terdapat unsur aktualisasi diri yang dipahamkan Maslow. Tidak adanya unsur ini bukan dikarenakan teori Jean Piaget belum sempurna atau unsur kreativitas yang dipaparkan Maslow. Melainkan karena kemampuan intelegensi anak memang belum sampai ke tahap itu. Bahkan walau agama telah dikenalkan dari bayi, namun tetap belum menemukan bentuknya yang sempurna, baik dari segi pemahaman apalagi pengamalan. Zakiah Darajat mengatakan bahwa kematangan beragama seseorang biasanya dimulai pada usia 24 tahun, baru dimulai, dan masih akan terus berkembang, bergantung kepada banyak faktor yang mempengaruhi, dan tidak ada limit bagi kematangan beragama. Walaupun pada 
masa anak-anak sudah mengenal konsep Tuhan versi mereka karena diperkenalkan oleh orang tuanya, namun pemahaman utuh dan benar mengenai agama baru tumbuh ketika memasuki masa dewasa awal.

Sejalan dengan kemampuan dan berfikir, maka kematangan pribadi sampai akhirnya mampu mengembangkan diripun, bukan sesuatu yang muncul begitu saja, ia merupakan sesuatu yang muncul perlahan-lahan dan menemukan bentuknya yang sempurna ketika semakin dewasa, itulah sebabnya dalam teori kognisi dan daya kreativitas Jean Piaget yang dilengkapi analisa tentang proses belajar serta pengaruh mileu, tidak menyebutkan perkembangan keagamaan dan kematangan pribadi untuk mengaktualisasikan dirinya.

\section{PERMAINAN TRADISIONAL JAWA}

Dunia anak adalah dunia bermain, dalam kehidupan anak-anak, sebagian besar waktunya dihabiskan dengan aktivitas bermain. Filsuf Yunani, Plato, merupakan orang pertama yang menyadari dan melihat pentingnya nilai praktis dari bermain. Anak-anak akan lebih mudah mempelajari aritmatika melalui situasi bermain. Bermain dapat digunakan sebagai media untuk meningkatkan keterampilan dan kemampuan tertentu pada anak. Istilah bermain diartikan sebagai suatu kegiatan yang dilakukan dengan mempergunakan atau tanpa mempergunakan alat yang menghasilkan pengertian, memberikan informasi, memberikan kesenangan, dan dapat mengembangkan imajinasi anak

Menurut Singer dalam Kusantanti, mengemukakan bahwa bermain dapat digunakan anak-anak untuk menjelajahi dunianya, mengembangkan kompetensi dalam usaha mengatasi dunianya dan 
mengembangkan kreativitas anak. Dengan bermain anak memiliki kemampuan untuk memahami konsep secara ilmiah, tanpa paksaan. Bermain menurut Mulyadi, secara umum sering dikaitkan dengan kegiatan anak-anak yang dilakukan secara spontan. Terdapat lima pengertian bermain: 13

Sesuatu yang menyenangkan dan memiliki nilai intrinsik pada anak

Tidak memiliki tujuan ekstrinsik, motivasinya lebih bersifat intrinsik

Bersifat spontan dan sukarela, tidak ada unsur keterpaksaan dan bebas dipilih oleh anak

Melibatkan peran aktif keikutsertaan anak

Memilikii hubungan sistematik yang khusus dengan seuatu yang bukan bermain, seperti kreativitas, pemecahan masalah, belajar bahasa, perkembangan sosial dan sebagainya

Banyak konsep dasar yang dapat dipelajari anak memalui aktivitas bemain. Pada usia prasekolah, anak perlu menguasai berbagai konsep dasar tentang warna, ukuran, bentuk, arah, besaran, dan sebagainya. Konsep dasar ini akan lebih mudah diperoleh anak melalui kegiatan bermain. Bermain, jika ditinjau dari sumber kegembiraannya di bagi menjadi dua, yaitu bermain aktif dan bermain pasif. Sedangkan jika ditinau dari aktivitasnya, bermain dapat dibagi menjadi empat, yaitu bermain fisik, bermain kreatif, bermain imajinatif, dan bermain manipulatif. Jenis bermain tersebut juga merupakan ciri bermain pada anak usia pra sekolah dengan menekankan permainan dengan alat (balok, bola, dan sebagainya) dan drama.

Permainan tradisional adalah jenis permainan yang mengandung nilai-nilai budaya pada hakikatnya merupakan warisan leluhur yang

13 Mulyadi S., Bermian dan Kreativitas (Upaya Mengembangkan Kreativitas Anak Melalui Kegiatan Bermain, (Jakarta : PT Sinar SInanti, 2004), hlm. 40. 
harus dilestarikan keberadaannya. ${ }^{14}$ Pada permainan tradisional terdapat bentuk permainan yang sifatnya bertanding (game) dan ada pula yang bersifat lebih mengutamakan untuk kegiatan mengisi waktu luang sebagai bentuk rekreasi atau kesenangan. Permainan tradisional Indonesia sangat beragam dan cara memainkannya tidak terlalu sulit.

Permainan tradisional adalah kekayaan khasanah budaya lokal, yang seharusnya dapat dimanfaatkan dalam pembelajaran pendidikan jasmani. ${ }^{15}$ Permainan tradisional merupakan permainan yang dimainkan oleh anak-anak Indonesia dengan alat-alat yang sederhana, tanpa mesin, bahkan ada yang hanya bermodal "awak waras" atau badan "badan sehat". Maksudnya, asalkan anak tersebut sehat, maka ia bisa ikut permainan. Permainan ini tidak hanya menggunakan alat yang sederhana tetapi juga bisa menggunakan badan sudah dapat bermain.

Permainan tradisional tumbuh dan berkembang berdasar kebutuhan masyarakat setempat. Kebanyakan permainan tradisional dipengaruhi oleh alam lingkungannya, oleh karena permainan ini selalu menarik, menghibur sesuai dengan kondisi masyarakat saat itu. Permainan tradisional adalah salah satu bentuk yang berupa permainan anak-anak yang beredar secara lisan di antara anggota kolektif tertentu, berbentuk tradisional dan diwarisi turun temurun serta banyak mempunyai variasi.16 Permainan tradisioanl bersifat turun temurun atau diwariskan dari nenek moyang kita terdahulu. Permainannya sangat sederhana dan mudah dilakukan oleh siapa saja tanpa terikat oleh usia tertentu. Karena sifat permainan tradisional sebagai

14 Andang Ismail, Education Games Menjadi Cerdas dan Ceria dengan Permainan Edukatif. Cetakan ke III. (Jogjakarta: Pilar Media 2009), hlm. 105

15 Pontjopoetro, dkk. Permainan Anak, Tradisional dan Aktivitas Ritmik (Modul 3), (Jakarta. Pusat Penerbitan UT 2002), hlm. 3

${ }^{16}$ Keen Achroni, Mengoptimalkan Tumbuh Kembang Anak Melalui Permainan Tradisional, (Jogjakarta: Javalitera 2012), hlm. 45 
permainan yang menyenangkan dan mengembirakan yang biasanya dilakukan pada sore hari.

Dari berbagai pengertian permainan tradisional, dapat disimpulkan bahwa permainan tradisional adalah permainan yang memiliki unsur-unsur budaya yang tumbuh dan berkembang dalam masyarakat sesuai dengan aturan dan norma adat kebiasaan yang diwarisi dan dipelihara secara turun temurun baik menggunakan alat atau tanpa alat dalam permainannya.

\section{E. JENIS PERMAINAN TRADISIONAL JAWA YANG DAPAT MEMBANGUN KREATIVITASANAK}

Indonesia merupakan Negara kepulauan yang memiliki keaneka ragaman budaya dan tradisi. Begitu pula dengan keaneka ragaman permainan-permainan tradisional yang telah ada sejak jaman nenek moyang. di setiap daerah memiliki permainan tradisional yang berbedabeda antara satu wilayah dengan wilayah lainnya yang disebabkan oleh perbedaan kultur dan kondisi wilayah serta lingkungan di masingmasing daerah. Walaupun terdapat jenis permainan yang sama antara satu wilayah dengan wilayah yang lain, pastinya nama permainan itu berbeda.

Bentuk permainan tradisional dan tata cara memainkannya.yang dapat membangun kretaivitas anak :

1. Galasin, atau gobak sodor

a. Mengenal galasin atau gobak sodor

Terdapat berbagai macam permainan tradisional yang berkembang di Indonesia. Salah satu permainan tradisional yang cukup popular dikalangan anak-anak adalah permainan galasin atau yang akrab disebut permainan gobak sodor. Galasin, atau gobak sodor adalah sejenis permainan daerah dari Indonesia. 
Istilah permainan Gobag sodor dikenal di daerah jawa tengah , sedangkan di daerah lain seperti galah lebih dikenal di Kepulauan Natuna, sementara di beberapa daerah Kepulauan Riau lainnya dikenal dengan nama galah panjang. Di daerah Riau Daratan, permainan galah panjang ini disebut main cak bur atau main belon. Sedang di daerah jawa barat di kenal dengan nama Galah Asin atau Galasin. Kemudian di makassar nama nya main asing. Adapun permainan daerah dari Bali yaitu gale-galean. Terdapat nama-nama yang berbeda dari satu daerah ke daerah lainnya. Akan tetapi permainan tersebut berbentuk sama.

b. Cara memainkan permainan gobak sodor

Permainan ini adalah sebuah permainan grup yang terdiri dari dua grup, di mana masing-masing tim terdiri dari 3 - 5 orang. Inti permainannya adalahmenghadang lawan agar tidak bisa lolos melewati garis ke baris terakhir secara bolak-balik, dan untuk meraih kemenangan seluruhanggota grup harus secara lengkap melakukan proses bolak-balik dalam area lapangan yang telah ditentukan.

Permainan ini biasanya dimainkan di lapangan dengan acuan garis-garis yang ada atau bisa juga dengan menggunakan lapangan segiempat yang dibagi menjadi 6 bagian. Garis batas dari setiap bagian biasanya diberi tanda dengan kapur. Anggota grup yang mendapat giliran untuk menjaga lapangan ini terbagi dua, yaitu anggota grup yang menjaga garisbatas horisontal dan garis batas vertikal. Bagi anggota grup yang mendapatkan tugas untuk menjaga garis batas horisontal, maka mereka akan berusaha untuk menghalangi lawan mereka yang juga berusaha untuk melewati garis batas yang sudah ditentukan sebagai garis batas bebas. Bagi anggota grup yang mendapatkan tugas untuk 
menjaga garis batas vertikal (umumnya hanya satu orang), maka orang ini mempunyai akses untuk keseluruhan garis batas vertikal yang terletak di tengah lapangan. Permainan ini sangat mengasyikkan sekaligus sangat sulit karena setiap orang harus selalu berjaga dan berlari secepat mungkin jika diperlukan untuk meraih kemenangan.

Berikut ini peraturan-peraturan yang berlaku dalam permainan gale-galean (Gobak Sodor) adalah sebagai berikut.

a. Pemain terbagi menjadi 2 kelompok yang terdiri dari $3-5$ orang.

b. Jika 1 kelompok terdiri dari 4 orang maka lapangan dibagi menjadi 4 kotak persegi panjang, yang berukuran $5 \mathrm{~m} \times 3 \mathrm{~m}$.

c. Tim penjaga bertugas menjaga agar tim lawan tidak bisa menuju garis finish

d. Tim lawan berusaha menuju garis finish dengan sayarat tidak tersentuh tim penjaga.

e. Tim lawan dikatakan menang apabila berhasil balik menuju garis start dengan selamat (tidak tersentuh tim lawan).

f. Salah satu tim bisa dikatakan menang apabila bisa kembali ke garis start dengan selamat untuktim lawan dan untuk tim penjaga di katakan menang apa bila bisa menyentuh salah satu anggota tim lawan.

Nilai kreativitas dalam permainan gobak sodor, selain kebersamaan, kita juga bisa belajar kerja sama yang kompak antara satu penjaga dan penjaga lain agar lawan tidak lepas kendali untuk keluar dari kungkungan kita. Di pihak lain bagi penerobos yang piawai, disana masih banyak pintu-pintu yang terbuka apabila satu celah dirasa telah tertutup. Jangan putus asa 
apabila dirasa ada pintu satu yang dijaga, karena masih ada pintu lain yang siap menerima kedatangan kita, yang penting kita mau mau berusaha dan bertindak segera.

\section{Petak Umpet}

a. Mengenal petak umpet

Petak umpet atau dalam bahasa Inggris Hide and Seek adalah salahsatu permainan tradisional anak-anak yang sudah sangat terkenal. Selain di Indonesia permainan ini juga sangat digemari oleh anak-anak diluar negeri. Petak Umpet adalah permainan rakyat tradisional umum di Seluruh pelosok Indonesia dari Sabang sampai merauke sejak dulu kala. Siapa saja boleh ikut, tetapi biasanya peserta permainan antara lima sampai sepuluh orang, karena bersifat mencari kawan yang bersembunyi, maka tidak terlalu banyak yang menjadi bagian dari permainan ini. Permainan ini sangat populer dibanding permainan tradisional yang lain karena permainan ini sangat mengasikan dan juga banyak manfaatnya.

b. Cara bermain Petak Umpet

Pertama kita harus menentukan seseorang yang kalah dan bertugas untuk mencari pemain lain yang mengumpet, biasanya pemilihan yang kalah dilakukan dengan "Hompimpa" . Setelah dipilih seseorang yang jaga, maka kita menentukan tempat yang digunakan sebagai "benteng" . Benteng ini bisa berupa tembok atau pohon. (tempat jaga ini memiliki sebutan yang berbeda di setiapdaerah, contohnya di beberapadaerah di Jakarta ada yang menyebutnya INGLO, di daerah lain menyebutnya BON, BUR dan ada juga yang menamai tempat itu HONG ). Setelah itu, yang kalah harus menghitung sampe angka yang ditentukan sambil 
menutup matanya menghadap benteng. Saat yang kalah menghitung, pemain lain harus cepat-cepat bersembunyi ditempat yang aman dan tidak mudah dilihat.

Setelah hitungan selesai, yang kalah harus menceri semua pemain lain yang bersembunyi sampai ketemu. Bila telah menemukan seseorang yang bersembunyi, yang kalah harus cepat-cepat berlari dan menepuk "benteng" sambil menyebut nama pemain yang telah ketauan tersebut dan jangan sampai pemain yang bersembunyi menepuk "benteng" itu lebih dulu.Menyebut nama ini sangat penting karena jika lupa menyebut nama pemain saat menepuk "benteng" maka pemain yang kalah harus mengulang menghitung dan membiarkan pemain lain bersembunyi lagi.

Setelah semuanya sudah ditemukan, maka yang kalah kembali menutup mata menghadap "benteng" dan pemain lain berdiri berbaris dibelakang pemain yang menutup mata. Sangpencari atau yang kalah bertugas untuk menyebut salah satu nomor secara acak. Pemain yang berada diurutan nomor tersebut adalah pemain yang harus menjadi pencari. Namun jika pemain yang berada diurutan nomer itu merupakan pemain yang lebih dulu menepuk benteng saat ketahuan tempat persembunyiannya, maka si pencari tetap dalam posisi kalah dan permainan pun dilanjutkan kembali.

Ada satu istilah lagi dalam permainan ini, yaitu 'kebakaran 'yang dimaksud di sini adalah bila teman kucing yang bersembunyi ketahuan oleh si kucing disebabkan diberitahu oleh teman kucing yang telah ditemukan lebih dulu dari persembunyiannya. Kreativitas yang kita dapat dari permainan peta umpet ini adalah sebagai berikut : 
a. Pintar berhitung karena permainan ini mengharuskan yangkalah untuk menghitung.

b. Olah raga dan menghilangkan kemungkinan obesitas bagi anak. Saat pencari menemukan tempat persembunyian pemain lain, maka pencari dan pemain itu harus berlomba untuk sampai ke benteng. Untuk mencapai benteng, kedua pemain ini akan berlari dan berlari inilah yang membuat anak berolah raga.

c. Mengasah ketelitian dan kepekaan. Manfaat ini sangat dirasakan oleh pencari maupun yang bersembunyi. Untuk pencari = ia bisa mengasah ketelitiannya dan kepekaannya dalam mengamati gerak gerik pemain lain dan juga tempattempat yang di jadikan tempat persembunyian. Yang dilakukan pencari seperti halnya berburu. Untuk yang bersembunyi $=$ ia akan lebih meneliti apakah tempat sembunyinya itu bagus dan aman. Selain itu, dia juga harus belajar membaca situsi di sekitar benteng dan mengamati gerak gerik pemain. Disamping itu,ia harus belajar untuk lihai dalam bersembunyi.

d. Melatih kesabaran. Mungkin manfaat ini sangat dirasakan olehpencari karena ia harus sabar untuk menemukan semua pemain. Selain itu, jika sang pencari haruskembali kalah maka dia harus membutuhkan kesabaran untuk mengulang menghitung, dan mencari pemain lain.

e. Melatih ingatan. Seperti yang dijelaskan diatas bahwa jika telahmenemukan pemain yang bersembunyi, pencari tidak boleh lupa untuk menyebut nama pemain itu sebelum menepuk benteng agar tidak kembali menjadi pemain yang kalah. Oleh karena itu, sang pencari harus bisa mengingat 
nama dan mengingat untuk menyebutkan nama agar tidak kalah lagi.

Permainan tradisional dalam membangun kretivitas dapat dibuktikan dengan banyaknya keterkaitan antara permainan tradisional dengan kretaivitas- kreativitas yang ada saat permainan tersebut. Diakui atau tidak permainan tradisional sudah berkurang, baik sarana maupun prasaran untuk bermain, kita sebagai generasi dari nenek moyang yang pernah mengalami masa kecil memainkan permainan tradisional memiliki kewajiban untuk meneruskan warisan budaya ini kepada generasi selanjutnya, dengan begitu anak-anak di masa yang akan datang dapat merasakan bermain permainan tradisional dan tumbuh menjadi anak yang cerdas dalam menjalani kehidupannya ketika dewasa.

\section{F. PENUTUP}

Permainan tradisional tidak hanya sekedar permainan yang mengandung kesenangan semata. Namun permainan tradisionaldapat membangun kretaifitas anak dan juga melatih kemampuan motorik anak,sikap anak, dan juga ketrampilan anak, Serta dapat membentuk karakter anak yang luhur. dalam menerima sikap perubahan sosial didalam masyrakat kita memang harus bersifat terbuka dan dinamis terhadap perkembangan zaman dan perkembangan dunia. Ada sebuah garis yang harus memisahkan kebudayaan asli dengan masuknya kebudayaan luar dalam era global saat ini. Perubahan sosial akanterjadi apabila masyarakat menerima masuknya perubahan itu sendiri, maka dari itu kita perlu 
yang namanya kesadaran sejak diniuntuk menjaga dan melstarikan kebudayaan lokal masyarakat kita sendiri, kalau bukan kita yang menjaga kebudayaan tersebut siapa lagi dan tidak akan menutup kemungkinan hilangnya permainan tradisional sebagai salah satu warisan dari nenek moyang kita.

\section{DAFTAR PUSTAKA}

Achroni, Keen, Mengoptimalkan Tumbuh Kembang Anak Melalui Permainan Tradisional, Jogjakarta: Javalitera 2012

Ali, Mohammad, dan Asrori, Mohammad, Psikologi Remaja: Perkembangan Peserta Didik, Jakarta: Bina Aksara, 2005

Bybee R.W. and R.B. Sund, Piaget for Educators, Ohio: Charles E. Merril, 1982

Cormak, Mc., Piagetian, A.J., Theory and the Development of Creative Thinking, Ohio:Charles E. Merril, 1982 
Haditono, Siti Rahayu, Psikologi Perkembangan: Pengantar dalam Berbagai Bidangnya, Yogyakarta: Gajah Mada University Press, 2004

Harms, Ernest, The Development OfReligious on Children, Ohio: Charles E. Merril, 1988

Ismail, Andang, Education Games Menjadi Cerdas dan Ceria dengan Permainan Edukatif, Cetakan ke III. Jogjakarta: Pilar Media, 2009

Kartono, Kartini, Psikologi Perkembangan Anak, Jakarta: CV Mandar Maju, 1995

Maslow, Abraham, Motivation and Personality, New York: Harper, 1945

Munandar, Utami, Mengembangkan Bakat dan Kreativitas Anak Sekolah, Jakarta: Gramedia Widiasarana Indonesia, 1992.

, Mengembangkan Bakat dan Kreativitas Anak Sekolah, Jakarta: Gramedia, 2004 , Pengembangan Kreativitas Anak Berbakat, Jakarta: PT Rineka Cipta,2009

Pontjopoetro, dkk. Permainan Anak, Tradisional dan Aktivitas Ritmik (Modul 3), Jakarta. Pusat Penerbitan UT 2002

S., Mulyadi, Bermain dan Kreativitas (Upaya Mengembangkan Kreativitas Anak Melalui Kegiatan Bermain, Jakarta : PT Sinar SInanti, 2004. 